Disclosure of Interest: None declared

DOI: 10.1136/annrheumdis-2018-eular.6484

\section{SAT0725-HPR COMPARATIVE ANALYSES OF RESPONSIVENESS BETWEEN THE RHEUMATOID ARTHRITIS IMPACT OF DISEASE (RAID) SCORE, OTHER PATIENT REPORTED OUTCOMES AND DISEASE ACTIVITY MEASURES: SECONDARY ANALYSES FROM THE ARCTIC STUDY}

K. Holten ${ }^{1,2}$, J. Sexton ${ }^{1}$, T.K. Kvien ${ }^{1,2}$, E.A. Haavardsholm ${ }^{1,2}$, A.-B. Aga ${ }^{1}$. ${ }^{1}$ Department of Rheumatology, Diakonhjemmet Hospital; ${ }^{2}$ Faculty of Medicine, University of Oslo, Oslo, Norway

Background: The RAID score is a patient-derived patient reported outcome measure (PROM), developed by a EULAR task force, that assesses the impact of RA on seven important domains. Responsiveness of the RAID score was assessed in the preliminary validation, ${ }^{1}$ but more data is needed on the sensitivity to change, especially compared to other PROMs and other conventional outcome measures.

Objectives: The objective of this study was to assess the changes in the RAID score in patients with early RA during the first six months of intensive DMARD treatment, and to evaluate the responsiveness of RAID after 3 months compared to other PROMs and conventional measures of disease activity.

Methods: RA patients with short disease duration were followed in the 24 month treat-to-target strategy ARCTIC trial. ${ }^{2}$ The responsiveness of the RAID score was evaluated by calculating the Standardised Response Mean (SRM) followed by the Relative Efficiency (RE) with respect to the Ritchie Articular Index. SRMs and RE were also calculated for other PROMs and clinical outcome measures. An SRM with absolute value above 0.80 was considered high.

Results: 230 RA patients were included. The mean symptom duration was 7.09 \pm 5.40 ( \pm SD) months, the baseline mean RAID score was $4.49 \pm 2.14$. At the 3 month follow-up, the mean change score for RAID was $-2.25 \pm 1.98$ and the SRM was $-1.13(-1.33$ to -0.96 ) (table 1$)$.

\begin{tabular}{|c|c|c|c|c|}
\hline & 3 months & & 6 months & \\
\hline & $\begin{array}{l}\text { Change, } \\
\text { mean } \pm S D\end{array}$ & SRM $(95 \% \mathrm{Cl})$ & $\begin{array}{l}\text { Change, } \\
\text { mean } \pm S D\end{array}$ & SRM $(95 \% \mathrm{Cl})$ \\
\hline RAID & $-2.25 \pm 1.98$ & $\begin{array}{c}-1.13(-1.33 \text { to } \\
-0.96)\end{array}$ & $-2.39 \pm 1.98$ & $\begin{array}{c}-1.21(-1.38 \text { to } \\
-1.06)\end{array}$ \\
\hline DAS & $-1.71 \pm 1.04$ & $\begin{array}{c}-1.63(-1.89 \text { to } \\
-1.42)\end{array}$ & $-1.95 \pm 1.09$ & $\begin{array}{c}-1.80(-2.04 \text { to } \\
-1.60)\end{array}$ \\
\hline ESR & $-10.9 \pm 15.0$ & $\begin{array}{c}-0.73(-0.83 \text { to } \\
-0.63)\end{array}$ & $-11.7 \pm 16.5$ & $\begin{array}{c}-0.71(-0.84 \text { to } \\
-0.59)\end{array}$ \\
\hline CRP & $-9.68 \pm 18.4$ & $\begin{array}{c}-0.53(-0.62 \text { to } \\
-0.43)\end{array}$ & $-10.8 \pm 19.5$ & $\begin{array}{c}-0.55(-0.63 \text { to } \\
-0.48)\end{array}$ \\
\hline Swollen joint count & $-8.86 \pm 6.89$ & $\begin{array}{c}-1.28(-1.46 \text { to } \\
-1.14)\end{array}$ & $-9.63 \pm 7.41$ & $\begin{array}{c}-1.30(-1.46 \text { to } \\
-1.17)\end{array}$ \\
\hline Ritchie Articular Index & $-5.75 \pm 6.03$ & $\begin{array}{c}-0.95(-1.12 \text { to } \\
-0.80)\end{array}$ & $-6.33 \pm 6.30$ & $\begin{array}{c}-1.01(-1.15 \text { to } \\
-0.88)\end{array}$ \\
\hline $\begin{array}{l}\text { Patient global } \\
\text { assessment VAS }\end{array}$ & $-28.3 \pm 24.2$ & $\begin{array}{c}-1.17(-1.35 \text { to } \\
-1.02)\end{array}$ & $-30.2 \pm 25.2$ & $\begin{array}{c}-1.20(-1.38 \text { to } \\
-1.05)\end{array}$ \\
\hline $\begin{array}{l}\text { Physician global } \\
\text { assessment VAS }\end{array}$ & $-26.2 \pm 19.2$ & $\begin{array}{c}-1.37(-1.54 \text { to } \\
-1.22)\end{array}$ & $29.2 \pm 20.7$ & $\begin{array}{c}-1.41(-1.58 \text { to } \\
-1.27)\end{array}$ \\
\hline $\begin{array}{l}\text { PROMIS physical } \\
\text { function }\end{array}$ & $14.8 \pm 13.7$ & $\begin{array}{c}1.08 \text { (0.96 to } \\
1.22)\end{array}$ & $15.5 \pm 14.0$ & $\begin{array}{c}1.11 \text { ( } 0.97 \text { to } \\
1.26)\end{array}$ \\
\hline Fatigue VAS & $-13.3 \pm 29.3$ & $\begin{array}{c}-0.45(-0.60 \text { to } \\
-0.32)\end{array}$ & $-16.0 \pm 29.8$ & $\begin{array}{c}-0.54(-0.68 \text { to } \\
-0.40)\end{array}$ \\
\hline Joint pain VAS & $-27.7 \pm 24.4$ & $\begin{array}{c}-1.14(-1.31 \text { to } \\
-0.98)\end{array}$ & $-29.5 \pm 25.2$ & $\begin{array}{c}-1.17(-1.35 \text { to } \\
-1.02)\end{array}$ \\
\hline $\begin{array}{l}\text { SF-36 Physical } \\
\text { component }\end{array}$ & $8.99 \pm 9.02$ & $\begin{array}{c}1.00(0.84 \text { to } \\
1.18)\end{array}$ & $9.19 \pm 9.47$ & $\begin{array}{c}0.97(0.83 \text { to } \\
1.14)\end{array}$ \\
\hline $\begin{array}{l}\text { SF-36 Mental } \\
\text { component }\end{array}$ & $3.89 \pm 10.6$ & $\begin{array}{c}0.37(0.23 \text { to } \\
0.52)\end{array}$ & $3.02 \pm 10.8$ & $\begin{array}{c}0.28(0.15 \text { to } \\
0.43)\end{array}$ \\
\hline
\end{tabular}

The RAID score was more efficient in detecting change than the Ritchie Articular Index and also demonstrated relatively high efficiency in detecting change compared to other PROMs and clinical outcome measures (figure 1).
Relative Efficiency

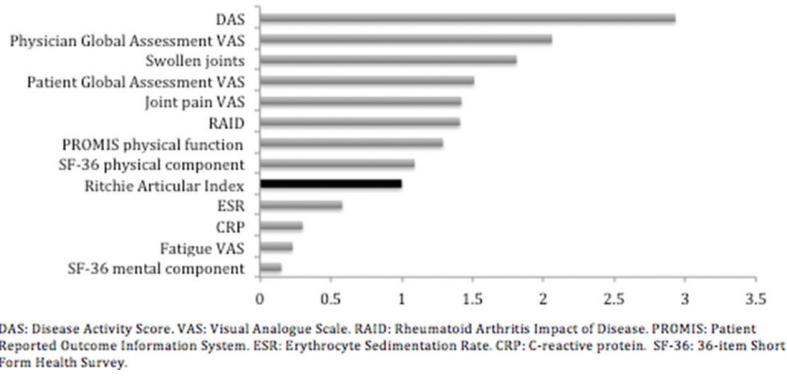

Abstract SAT0725HPR - Figure 1. Relative efficiency to tender joint count (Ritchie Articular Index) of the various outcomes reflecting disease activity at 3 months follow-up (Ritchie Articular Index = reference with a relative efficiency of 1.00).

Conclusions: The RAID score proved to be highly responsive to change in RA patients with short disease duration who followed a treat-to-target strategy. The RAID score was efficient in detecting change compared to other PROMs and conventional disease activity measures.

\section{REFERENCES:}

[1] Gossec, et al. ARD 2011;70:935-42.

[2] Haavardsholm, et al. BMJ 2016;354:i4205, 2016

Disclosure of Interest: K. Holten: None declared, J. Sexton: None declared, T K. Kvien: None declared, E. A. Haavardsholm Grant/research support from: Pfizer, UCB, Roche, MSD and AbbVie, A.-B. Aga: None declared DOI: 10.1136/annrheumdis-2018-eular.2889

\section{SAT0726-HPR IMPROVEMENT OF HAND FUNCTION, PHYSICAL CAPACITY AND QUALITY OF LIFE OF SYSTEMIC SCLEROSIS PATIENTS AFTER AUTOLOGOUS HEMATOPOIETIC STEM CELL TRANSPLANTATION}

K.R. Costa Pereira ${ }^{1}$, J.B. Elias ${ }^{1}$, D.A. Moraes ${ }^{1}$, A.L.C. Guimaraes ${ }^{2}$, J.T. Garcia ${ }^{2}$, M. C. Oliveira ${ }^{3}$, V. Leopoldo ${ }^{3}$, A.F. Zombrilli ${ }^{3}$, T.M. Costa ${ }^{1}$, A.B.P. Stracieri' ${ }^{1}$, B. P. Simoes ${ }^{4}$, M.C.C. Oliveira ${ }^{1}{ }^{1}$ Division of Clinical Immunology Ribeirao Preto Medical School; ${ }^{2}$ Ribeirão Preto School of Philosophy, Sciences and Literature;

${ }^{3}$ Ribeirao Preto School of Nursing; ${ }^{4}$ Division of Hematology, Ribeirao Preto Medical School, University of Sao Paulo, Ribeirao Preto, Brazil

Background: Systemic sclerosis (SSc) is characterised by skin thickening and visceral involvement, leading to impairment of physical function, daily life activities and quality of life. Severe cases usually have poor prognosis, despite conventional immunosuppressive treatment. Autologous hematopoietic stem cell transplantation (AHSCT) has been investigated as treatment for patients with severe SSc and promotes reduction of skin thickening and at least stabilisation of visceral involvement. There are no reports in the literature addressing the influence of AHSCT on hand function and physical capacity of SSc patients.

Objectives: To evaluate the impact of AHSCT on skin involvement, hand function, physical capacity and quality of life (QoL) of SSc patients.

Methods: This is a prospective longitudinal study of a cohort of 27 SSc patients who underwent AHSCT at a University Hospital in the state of São Paulo, Brazil. Patients were evaluated before, and at 6,12 and 24 months after transplant. The evaluations included modified Rodnan skin score (mRSS), hand function (handgrip strength, finger-to-palm distance - FTP, range of motion measures, DASH and COCHIN questionnaires), mouth opening, six-minute walk test (6MWT) and quality of life questionnaire (SF-36). Results were subjected to statistical analyses and significance levels were established at $p<0.05$.

Results: Twenty-seven patients were evaluated before and at 6 months after transplant, 22 of which were additionally evaluated at 12 months, and 13 patients at 24 months post-transplant. At 12 months after AHSCT, patients presented significant improvement of mRSS $(p<0.01)$, hand grip strength $(p<0.01)$, range of motion of hands ( $p<0.01$, except for I metacarpophalangeal joints of both hands), FTP distance $(p<0.01)$, DASH $(p<0.01)$, COCHIN $(p<0.01)$, mouth opening $(p<0.01), 6 M W T$ distance $(p=0.01)$, and physical $(p<0.01)$ and mental $(p=0.02)$ components of the SF-36, when compared to pre-transplant evaluations. Significant correlations were observed between skin involvement and range of motion measures (dominant hand: $R=-0.65, p<0.01$; non-dominant hand: $R=-0.59$, 